\title{
LIST OF MAPS AND GENEALOGIES
}

\section{Maps}

1 The German kingdom and its eastern neighbours in the twelfth century

2 The world of Wiprecht of Groitzsch

3 Groitzsch and its environs

4. The world of Otto of Bamberg 99

5 Arnstein and its environs 226

\section{Genealogies}

Wiprecht's genealogy, according to The deeds of Wiprecht of Groitzsch

Ludwig's genealogy, according to The deeds of Count Ludwig of Arnstein 